\title{
An index approach to heavy metal pollution assessment of Eme River, Umuahia, Nigeria.
}

\section{Un enfoque de índice para la evaluación de la contaminación por metales pesados del río Eme, Umuahia, Nigeria}

\author{
Emeka Donald Anyanwu ${ }^{1}$ and Solomon Nnanna Umeham² \\ ${ }^{1}$ Department of Zoology and Environmental Biology, \\ Michael Okpara University of Agriculture, Umudike, Nigeria. \\ ${ }^{2}$ Department of Animal and Environmental Biology, \\ Abia State University, Uturu, Nigeria. \\ Emeka Donald Anyanwu: ekadon@yahoo.com \\ Solomon Nnanna Umeham: solo2010@gmail.com
}

\begin{abstract}
Rivers are subjected to various kinds of natural events and anthropogenic activities among which, indiscriminate and illegal sand mining is a major one. The heavy metal content of a Nigerian river was studied between December 2017 and November 2018 in 6 stations. The objective of the study was to assess the water quality using heavy metal pollution indices for drinking water purpose. It is cumbersome to interpret the results of water quality assessment when it involves large number of parameters hence the index approach. The indices used were Heavy Metal Pollution Index (HPI) and Contamination Index $\left(\mathrm{C}_{d}\right)$. Eight metals were evaluated using standard methods and compared with Nigerian Drinking Water Quality Standard. Some metals like iron, cadmium and lead exceeded limits; manganese, chromium and nickel exceeded limits in the dry season in some stations while copper and zinc were all within limits. The dry season values were significantly $(P<0.05)$ higher than the wet season values. HPI showed all the stations exceeded the threshold (100) especially stations 1, 4 - 6 while $C_{d}$ showed that stations 3 and 2 had low and medium contamination potential risks respectively and stations 1, $4-6$ had high contamination potential risks. The indices effectively captured the effect of the anthropogenic activities (sand mining, swimming, washing, etc) in the river and showed that the water quality was not suitable for human consumption.
\end{abstract}

Keywords: Limits, HPI, Heavy metal, water quality, indices.

\section{RESUMEN}

Los ríos están sujetos a varios tipos de actividades naturales y antropogénicas, entre las cuales la minería de arena indiscriminada e ilegal es una de las principales. El contenido de metales pesados de un río nigeriano se estudió entre diciembre de 2017 y noviembre de 2018 en 6 estaciones. El objetivo del estudio fue evaluar la calidad del agua utilizando índices de contaminación por metales pesados para fines de agua potable. Es engorroso interpretar los resultados de la evaluación de la calidad del agua 
cuando involucra una gran cantidad de parámetros, de ahí el enfoque del índice. Los índices utilizados fueron el índice de contaminación por metales pesados (HPI) y el índice de contaminación (Cd). Se evaluaron ocho metales utilizando métodos estándar y se compararon con el Estándar de calidad del agua potable de Nigeria. Algunos metales como el hierro, el cadmio y el plomo excedieron los límites; el manganeso, el cromo y el níquel excedieron los límites en la estación seca en algunas estaciones, mientras que el cobre y el zinc estuvieron dentro de los límites. Los valores de la estación seca fueron significativamente $(P<0.05)$ más altos que los valores de la estación húmeda. HPI mostró que todas las estaciones excedieron el umbral (100) especialmente las estaciones $1,4-6$, mientras que Cd mostró que las estaciones 3 y 2 tenían riesgos potenciales de contaminación baja y media respectivamente y las estaciones 1, 4 - 6 tenían riesgos potenciales de contaminación altos. Los índices capturaron efectivamente el efecto de las actividades antropogénicas (extracción de arena, natación, lavado, etc.) en el río y mostraron que la calidad del agua no era adecuada para el consumo humano.

Palabras clave: Límites, HPI, metales pesados, calidad del agua, índices.

\section{INTRODUCTION}

The surface water bodies are among the most sensitive sources that could be impacted by human activities which may result in degradation of the resource in the future (Afkhami et al., 2013; Roshan et al., 2013). Monitoring of heavy metal contamination in rivers is important because heavy metals pose threat to aquatic life, human health and to the environment due to biomagnification and their toxicity (Ahmed et al., 2015; Ali et al., 2016). The term "heavy metals" refers to any metallic element that has relatively high density and applies to the group of metals and metalloids with atomic density greater than $5 \mathrm{~g} / \mathrm{cm}^{3}$ (Oves et al., 2012).

The heavy metals in water could be derived from both natural (weathering and erosion of bed rocks and ore deposits) and anthropogenic (mining, industries, wastewater irrigation and agriculture activities) sources (Ahmet et al., 2003; Anyanwu \& Onyele, 2018). Heavy metals may contaminate the surface water and groundwater resulting in deterioration of drinking and irrigation water quality (Krishna et al., 2009). Some of the heavy metals considered as micronutrients can cause adverse effects to human health when their contents exceed the permissible limit in drinking water (Prasanna et al., 2011; Prasad et al., 2014).

Heavy metals are serious environmental pollutants with toxicity tendency, longevity and persistency in the environment (Klavins et al., 2000; Tam \& Wong, 2000; Pekey et al., 2004; Hakan, 2006). A number of studies on heavy metal pollution of water resources have been carried out around the world (Muhammad et al., 2011; Kelepertzis, 2014; Ojekunle et al., 2016; Biswas et al., 2017).

Heavy metal concentrations in aquatic ecosystems are usually monitored by measuring their concentration in water (Ebrahimpour \& Mushrifah, 2008; Balakrishnan \& Ramu 2016). Popović et al. (2016) reported that it is not always easy to interpret the results in water quality assessment when a large number of parameters are involved; as some of these parameters are individually influenced by different anthropogenic stressors. Using fewer parameters will on the other hand affect the credibility of the assessment method (Anyanwu \& Umeham, 2020). A number of indices have been developed for the purpose of assessment of water quality. Quality indices are useful in getting a composite influence of all parameters on overall pollution. It also makes the assessments into a reproducible form and compiles all the pollution parameters into some easy approach (Balakrishnan \& Ramu, 2016). In order 
to evaluate the risk potential of heavy metal pollution in the river, two indices namely heavy metal pollution index (HPI) and contamination index (Cd) were used.

The objective of the study was to assess the water quality of Eme River, Umuahia, Nigeria using heavy metal pollution indices for drinking water purpose.

\section{MATERIALS AND METHODS}

Study Area: Eme River took its source from Uzoakoli in Abia State, Nigeria and transverse through many communities (including Ofeme) before discharging into Imo River at Onuimo. The stretch of Eme River studied was between Ofeme and Umudiawa across the Port Harcourt - Enugu expressway in Umuahia, Abia State; about $3.25 \mathrm{~km}$ in length (Figure 1). It lies between latitude $5^{\circ} 38^{\prime}$ and $5^{\circ} 37^{\prime} \mathrm{N}$ and Longitude $7^{\circ} 25^{\prime}$ and $7^{\circ} 26^{\prime} \mathrm{E}$. Station 1: located within the community at Mbato, Ofeme was upstream and the control station. The human activities observed especially during the dry season were laundry, swimming and extraction of drinking water. The substrate was muddy. Stations 2 - 6 were within the dredged section of the river. Station 2 was located at Eme - Ihite, Ofeme about $1.84 \mathrm{~km}$ downstream of Station 1. It is a less active sand mining site; minimal laundry, swimming and extraction of drinking water were observed. The substrate was a mixture of sand and stones. Station 3 was located at Eme - Ihite, Ofeme, about $419.67 \mathrm{~m}$ downstream of Station 2. No activities were observed except periodic boat movements. The substrate was made up of large clayey boulders. Station 4 was located at Umudiawa, about $490.26 \mathrm{~m}$ downstream of both Station 3 and an area of intensive sand mining activities and two sand landing sites. The substrate was sandy. Station 5 was located at Umudiawa, about $200.22 \mathrm{~m}$ downstream of Station 4. Sand mining activities was observed as the substrate was sandy. Station 6 was located at Umudiawa, about $300.14 \mathrm{~m}$ downstream of Station 5 with sandy substrate. Sand mining activities occurred within the water channel and around the shores. The sand miners use the river water around Stations 4-6 for drinking purpose among other things.

Field and laboratory work: Water samples were collected from Eme River monthly from December 2017 to November 2018. The samples were collected with a 1 litre water sampler, transferred into a clean $250 \mathrm{ml}$ plastic bottle and acidified with Nitric acid $\left(\mathrm{HNO}_{3}\right)$ according to Sharma \& Tyagi (2013). The water samples were digested using concentrated Analar Nitric acid according to Zhang (2007). The UNICAM Solaar 969 atomic absorption spectrometer (AAS) which uses acetylene-air flame was used for the determination of Heavy Metals.

Data analysis: All the results were statistically analysed using single factor ANOVA and Tukey Pairwise test was performed to determine the location of significant difference. The PAST software package (Version 3.24) was used in the analysis (Hammer et al., 2001). 


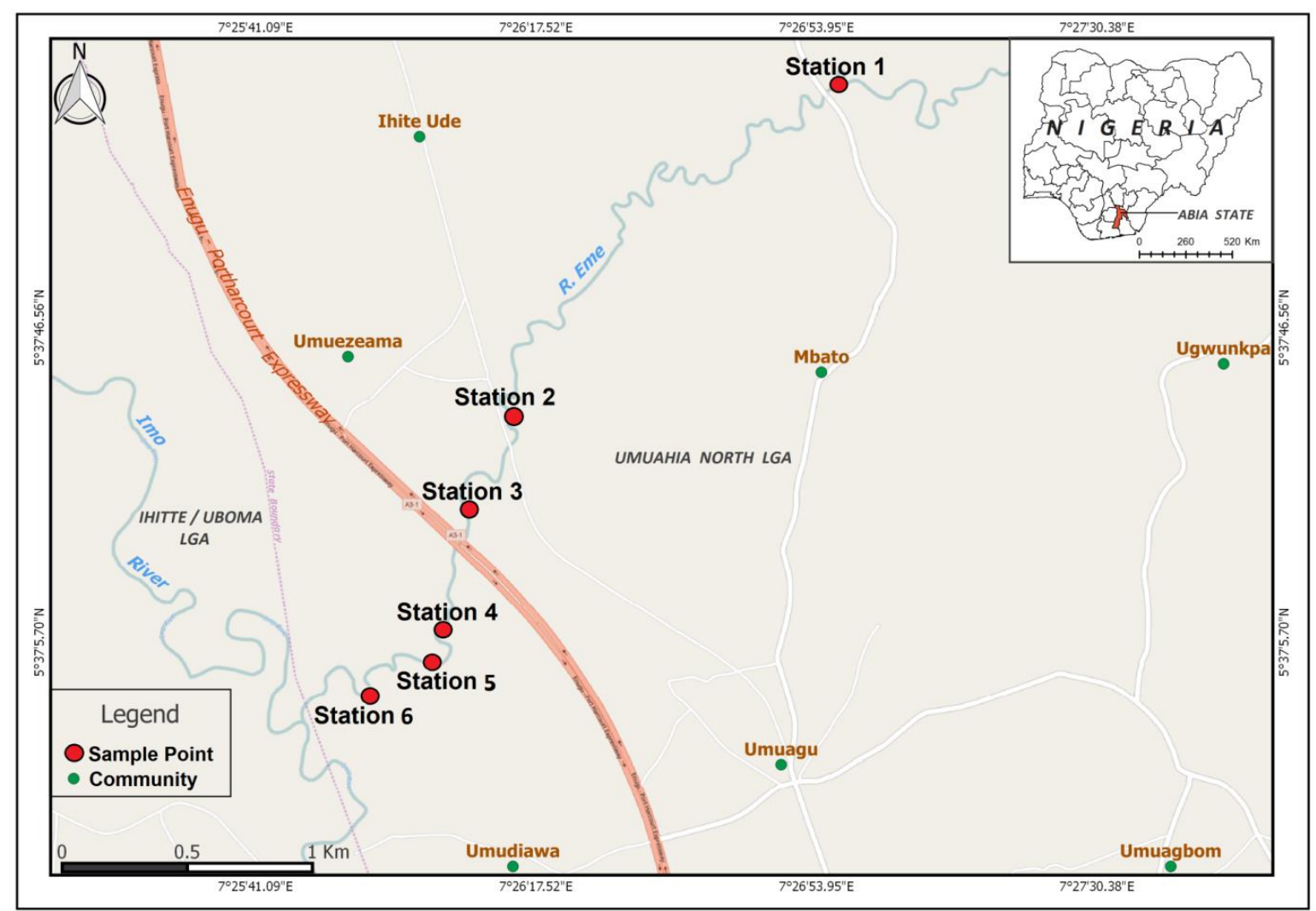

Figure 1: Map of Umuahia, Abia State, Nigeria showing the sampling Stations of Eme River.

Pollution Evaluation Indices: The assessment methods used this study was the Heavy metal pollution index (HPI) proposed by Prasad \& Bose (2001) and the Contamination index $\left(C_{d}\right)$ developed by Backman et al. (1997).

Heavy Metal Pollution Index: Based on weighted arithmetic mean method, HPI indicates the total quality of water with respect to heavy metals (Horton, 1965; Mohan et al., 1996). In order to compute HPI, unit weightage (Wi) is considered as a value inversely proportional to the recommended standard $(\mathrm{Si})$ of the relevant parameter (Prasad \& Bose, 2001). HPI (Mohan et al., 1996) was calculated as:

$$
\mathrm{HPI}=\frac{\sum q_{i} x W_{i}}{\sum W_{i}}
$$

Where, $q \mathrm{i}$ is the sub-index of ith parameter. $W \mathrm{i}$ is the unit weightage of ith parameter and $\mathrm{n}$ is the number of parameters considered.

$$
q i=100 \times \frac{c_{i}}{s_{i}}
$$

The sub-index ( $q \mathrm{i})$ of each parameter is defined by: where $\mathrm{Ci}$ is the measured value of ith parameter, while $S i$ is the recommended standard value of ith parameter. The critical value of HPI for drinking purposes as given by Prasad \& Bose (2001) is 100. In computing the HPI for the present study, eight (8) heavy metals ( $\mathrm{Mn}, \mathrm{Cu}, \mathrm{Pb}$, $\mathrm{Fe}, \mathrm{Zn}, \mathrm{Cd}, \mathrm{Cr}$ and $\mathrm{Ni}$ ) were considered and the weightage (Wi) was taken as the inverse of standard permissible value which is the Nigerian Standard for Drinking Water Quality (2015)

Contamination Index: Contamination index calculates the relative contamination of different metals separately and present the sum of generated components as a representative (Backman et al., 1997). Contamination index is calculated via the following equation:

$$
\mathrm{C}_{\mathrm{d}}=\sum_{i=0}^{n} C_{f i}
$$




$$
\text { Where } \mathrm{Cf}_{\mathrm{i}}=\left(\frac{C A_{i}}{C N_{i}}\right)-1
$$

$\mathrm{Cf}_{\mathrm{i}}=$ contamination factor for $\mathrm{i}$-th component.

$\mathrm{CA}_{\mathrm{i}}=$ analytical value for $\mathrm{i}$-th component.

$\mathrm{CN}_{\mathrm{i}}=$ upper permissible concentration of $\mathrm{i}$-th component. ( $\mathrm{N}$ denotes the 'normative value').

The low, medium and high contamination levels are referred to $C_{d}$ values of less than 1 , between 1 and 3 and greater than 3 , respectively. $\mathrm{CN}_{\mathrm{i}}$ is considered as the standard permissible value $\left(\mathrm{S}_{\mathrm{i}}\right)$ used in the calculation of HPI. These methods have been widely used by the various scientists (Nasrabadi, 2015; Biswas et al., 2017).

\section{RESULTS}

Heavy Metal Content: The heavy metal content of Eme River is presented in Table 1 . Spatially, the downstream stations $(4-6)$ were generally higher than the upstream stations $(1-3)$ in all the metals and seasonally, the dry season months (December - May) were significantly higher $(P<0.05)$ than the wet season months (June - November) in all the metals.

The iron values ranged from $0.36 \mathrm{mg} / \mathrm{l}$ (Station 3) to $6.28 \mathrm{mg} / \mathrm{l}$ (Station 4). All the values exceeded limit $(0.3 \mathrm{mg} / \mathrm{l})$ set by SON (2015). Station 4 was significantly different $(P<0.05)$ from Stations $1-3$ and 5.

The zinc values ranged from $0.10 \mathrm{mg} / \mathrm{l}$ (Station 3 ) to $1.64 \mathrm{mg} / \mathrm{l}$ (Station 5); all the zinc values were below the acceptable limit $(3 \mathrm{mg} / \mathrm{l})$. Station 4 was significantly different $(P<0.05)$ from Stations $1-3$.

Chromium values ranged from $0.008 \mathrm{mg} / \mathrm{l}$ (Station 2) to $0.06 \mathrm{mg} / \mathrm{l}$ (Station 5 ). A few of the values exceeded limit $(0.05 \mathrm{mg} / \mathrm{l})$ in Stations 1,4 and 5 during the dry season. Station 4 was significantly different $(P<0.05)$ from Stations $1-3$ and 5.

The nickel values ranged from $0.002 \mathrm{mg} / \mathrm{l}$ (Station 3) to $0.03 \mathrm{mg} / \mathrm{l}$ (Stations 1, 4 and 5). A few of the values exceeded limit $(0.02 \mathrm{mg} / \mathrm{I})$ in Stations 1,4 and 5 during the dry season. Station 4 was significantly different $(P<0.05)$ from Stations $1-3$ and 5 .

The lead values ranged from $0.005 \mathrm{mg} / \mathrm{l}$ (Station 3) to $0.08 \mathrm{mg} / \mathrm{l}$ (Station 5). All the values exceeded limit $(0.01 \mathrm{mg} / \mathrm{l})$ in except a few in Station 3 during the wet season.

Station 4 was significantly different $(P<0.05)$ from Stations $1-3$ and 5.

The cadmium values ranged from $0.003 \mathrm{mg} / \mathrm{l}$ (Station 3) to $0.05 \mathrm{mg} / \mathrm{l}$ (Station 5). All the values exceeded limit $(0.003 \mathrm{mg} / \mathrm{l})$ except one in Station 3 during the wet season. Station 4 was significantly different $(P<0.05)$ from Stations 2 and 3.

The copper values ranged from $0.02 \mathrm{mg} / \mathrm{l}$ (Stations $1-3$ ) to $0.27 \mathrm{mg} / \mathrm{l}$ (Station $4)$. All the values were within limit $(1 \mathrm{mg} / \mathrm{l})$. Station 4 was also significantly different $(\mathrm{P}<0.05)$ from Stations $1-3$.

The manganese values ranged from $0.01 \mathrm{mg} / \mathrm{l}$ (Station 3 ) to $0.42 \mathrm{mg} / \mathrm{l}$ (Station 4). All the values were within limit $(0.2 \mathrm{mg} / \mathrm{l})$ except a few in Stations $4-6$ during the dry season. Station 4 was also significantly different $(P<0.05)$ from Stations $1-3$ 


\begin{tabular}{|c|c|c|c|c|c|c|c|c|}
\hline Parameter & Stn 1 & Stn 2 & Stn 3 & Stn 4 & Stn 5 & Stn 6 & $\begin{array}{c}\text { P- } \\
\text { Value }\end{array}$ & $\begin{array}{c}\text { SON } \\
(2015)\end{array}$ \\
\hline \multirow[t]{2}{*}{ Iron } & $1.0 \pm 0.13^{a}$ & $1.0 \pm 0.18^{\mathrm{a}}$ & $0.7 \pm 0.07^{a}$ & $2.6 \pm 0.39^{c}$ & $1.5 \pm 0.31^{\mathrm{ab}}$ & $1.8 \pm 0.32^{\mathrm{abc}}$ & $*$ & 0.3 \\
\hline & $0.57-2.41$ & $0.40-2.81$ & $0.36-1.14$ & $1.36-6.28$ & $0.72-4.60$ & $0.98-5.12$ & & \\
\hline \multirow[t]{2}{*}{ Zinc } & $0.53 \pm 0.06^{\mathrm{ab}}$ & $0.49 \pm 0.08^{\mathrm{ab}}$ & $0.40 \pm 0.06^{a}$ & $0.99 \pm 0.09^{c}$ & $0.79 \pm 0.10^{b c}$ & $0.71 \pm 0.08^{\mathrm{abc}}$ & $*$ & 3 \\
\hline & $0.24-0.98$ & $0.17-1.10$ & $0.10-0.77$ & $0.54-1.58$ & $0.39-1.64$ & $0.45-1.37$ & & \\
\hline \multirow[t]{2}{*}{ Chromium } & $0.02 \pm 0.003^{\mathrm{ab}}$ & $0.02 \pm 0.004^{\mathrm{ab}}$ & $0.01 \pm 0.002^{a}$ & $0.04 \pm 0.003^{c}$ & $0.02 \pm 0.003^{b d}$ & $0.03 \pm 0.002^{\mathrm{bcd}}$ & $*$ & 0.05 \\
\hline & $0.01-0.05$ & $0.008-0.05$ & $0.005-0.03$ & $0.02-0.05$ & $0.01-0.06$ & $0.02-0.04$ & & \\
\hline \multirow[t]{2}{*}{ Nickel } & $0.01 \pm 0.002^{\mathrm{b}}$ & $0.008 \pm 0.001^{a}$ & $0.005 \pm 0.001^{a}$ & $0.02 \pm 0.001^{c}$ & $0.009 \pm 0.002^{\mathrm{ab}}$ & $0.01 \pm 0.001^{\mathrm{bcd}}$ & $*$ & 0.02 \\
\hline & $0.005-0.03$ & $0.003-0.02$ & $0.002-0.01$ & $0.008-0.03$ & $0.005-0.03$ & 0.006 & & \\
\hline \multirow[t]{2}{*}{ Lead } & $0.02 \pm 0.003^{a b}$ & $0.02 \pm 0.003^{a b}$ & $0.008 \pm 0.001^{a}$ & $0.05 \pm 0.005^{c}$ & $0.02 \pm 0.007^{\mathrm{ad}}$ & $0.03 \pm 0.004^{b c d}$ & $*$ & 0.01 \\
\hline & $0.01-0.04$ & $0.009-0.04$ & $0.005-0.02$ & $0.02-0.07$ & 0.01-0.09 & $0.01-0.06$ & & \\
\hline \multirow[t]{2}{*}{ Cadmium } & $0.02 \pm 0.003^{b c}$ & $0.01 \pm 0.002^{\mathrm{ab}}$ & $0.007 \pm 0.001^{a}$ & $0.03 \pm 0.004^{c}$ & $0.02 \pm 0.003^{b c}$ & $0.02 \pm 0.003^{b c}$ & $*$ & 0.003 \\
\hline & $0.009-0.04$ & $0.007-0.02$ & $0.003-0.01$ & $0.01-0.05$ & $0.009-0.05$ & $0.01-0.05$ & & \\
\hline \multirow{2}{*}{ Copper } & $0.07 \pm 0.007^{a b}$ & $0.05 \pm 0.005^{\mathrm{ab}}$ & $0.02 \pm 0.002^{a}$ & $0.12 \pm 0.015^{c}$ & $0.09 \pm 0.014^{b c}$ & $0.09 \pm 0.013^{b c}$ & * & 1 \\
\hline & $0.02-0.09$ & $0.02-0.07$ & $0.02-0.03$ & $0.07-0.27$ & $0.04-0.19$ & $0.04-0.21$ & & \\
\hline \multirow[t]{2}{*}{ Manganese } & $0.10 \pm 0.006^{b}$ & $0.10 \pm 0.007^{a b}$ & $0.05 \pm 0.005^{a}$ & $0.19 \pm 0.023^{c}$ & $0.14 \pm 0.016^{b c}$ & $0.15 \pm 0.014^{b c}$ & $*$ & 0.2 \\
\hline & $0.06-0.15$ & $0.05-0.13$ & $0.01-0.08$ & $0.11-0.42$ & $0.07-0.28$ & $0.08-0.25$ & & \\
\hline HPI & 329.1 & 227.3 & 122.3 & 619.8 & 330 & 392.7 & & \\
\hline$C_{d}$ & 5.65 & 2.17 & -1.69 & 18.87 & 7.57 & 9.85 & & \\
\hline
\end{tabular}

$a, b=$ Means with different superscripts across the rows are significantly different at $p<0.05$;

SEM = Standard Error of Mean; SON (2015) = Nigerian standard for drinking water quality; $*=$

$P<0.05$ 
Pollution Indices: The results obtained for the HPI and $\mathrm{C}_{d}$ from the sampling stations are presented in Table 1 . The behaviour of two indices among different sampling points is shown in Figs 2 and 3. The HPI results were all found to exceed the threshold value (100) and ranged from 122.3 (Station 3) to 619.8 (Station 4); reflecting the effects of geogenic and anthropogenic activities (Fig 2). The $C_{d}$ results followed the same trend as the HPI; the lowest was recorded in Station 3 while the highest was recorded in Station 4. It varied from -1.69 to 18.87 ; also reflecting the effects of the geogenic and anthropogenic activities (Fig. 3). The results indicated that stations 3 and 2 had low and medium pollution potential risks while stations $1,4-6$ had high pollution potential risk.

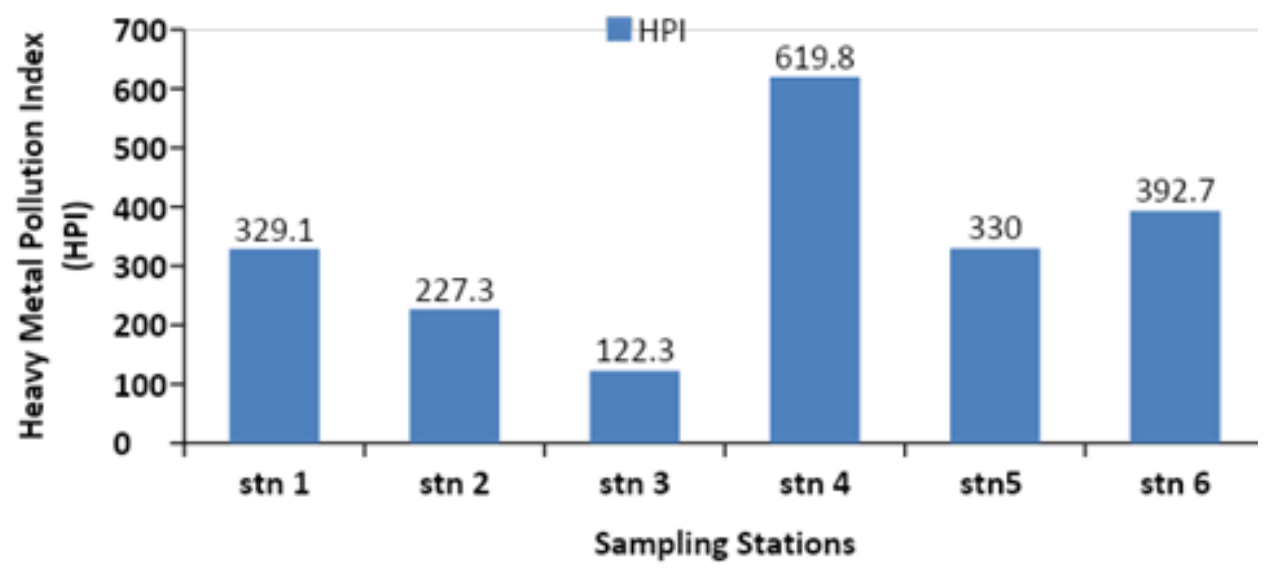

Fig. 2: The values of the HPI recorded in Eme River, Umuahia, Southeast Nigeria.

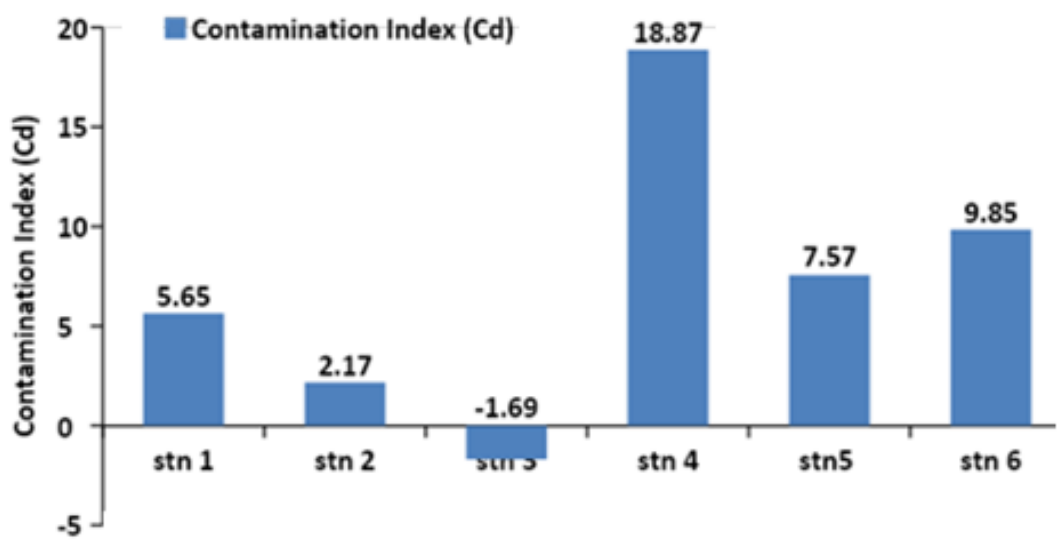

Fig. 3: The behaviour of Contamination Index $\left(C_{d}\right)$ among the stations of Eme River, Umuahia, Southeast Nigeria.

\section{DISCUSSION}

The results showed a trend among the behaviour of different metals in water of the river which may be attributed to their same impact source. Sediment-associated pollutants can influence the concentrations of metals in both the water column and biota if they are desorbed or become available (Milenkovic et al., 2005).

The main sources are considered to be geogenic exacerbated by anthropogenic activities such as sand mining. Sand mining of the bed, banks, riparian zone and floodplains of rivers are known to cause major morphological and hydrological changes that impact both on their functioning and on riverine habitats and biota (Pillay et al., 2014). 
Spatially, the downstream stations (4-6) were generally higher than the upstream stations (1-3) in all the metals. The sand mining activities was more intense around the downstream stations especially in the wet season. Pillay et al. (2014) confirmed a general increase in metal concentrations downstream of mining operations with some minor variations.

Iron and cadmium exceeded limits throughout the study and could be attributed to geogenic impact exacerbated by sand mining; one cadmium value was within limit in Station 3 during the wet season. Fe is usually more abundant in freshwater environment than other metals in Nigeria, due to its high occurrence on Earth (Adefemi et al., 2004; Aiyesanmi, 2006; Kumar et al., 2010). Lead exceeded limit except a few values in Station 3 during the wet season while chromium, nickel and manganese were all within limits except a few values in Stations $1,4-6$ in the dry season. Station 1 is within the village and is usually subjected to intense human visitation and activities during the dry season while dry season sand mining was sometimes observed around Stations 4-6.

The seasonal variations observed could be attributed to low precipitation, higher atmospheric temperatures resulting in higher evapotranspiration rates leading to concentration and higher values in the dry season while lower values during the wet season may be due to dilution by rain water (Atobatele \& Olutona, 2013; Etesin et al., 2013; Houssou et al., 2017). Zinc and copper were generally low and within limits.

The convergence of both indices (Heavy Metal Pollution Index and Contamination Index) in this study was of interest; reflecting the effects of geogenic and anthropogenic activities. All the HPI values exceeded the threshold value (Prasad \& Bose, 2001). The $C_{d}$ values followed the same trend with the HPI. The results indicated that stations 3 and 2 had low and medium pollution potential risks while stations 1, $4-6$ had high pollution potential risk. Ojekunle et al. (2016) recorded HPI values within the range of this study $(116.94$ - 229.25) in a stream around Lafenwa scrap yard in Abeokuta, Ogun State while Nasrabadi (2015) had low contamination index value of between -5.197 and -1.734 in Haraz River basin in Iran.

As conclusions, the study revealed the impact of anthropogenic sources on the heavy metal pollution load of the water in the river. The heavy metal pollution index (HPI) of Eme River was found to be above the critical index value 100, due to impermissible values of $\mathrm{Fe}, \mathrm{Cd}$ and $\mathrm{Pb}$ in the water. The contamination index $\left(\mathrm{C}_{d}\right)$ was also found to be high within the areas of intense sand mining activities. Based on the foregoing, the water was considered not fit for human consumption. Concrete measures must be taken to regulate sand mining activities and its associated impact on the heavy metal content of the river.

\section{ACKNOWLEDGEMENTS}

The study map was produced by Mr. Chinedu Ogbodo of Department of Geography, University of Nigeria, Nsukka, Nigeria. The authors hereby acknowledge his contribution.

\section{REFERENCES}

Adefemi, O. S., O. Olaofe \& S. S. Asaolu. 2004. Concentration of Heavy Metals in Water, Sediment and Fish parts (Illisha africana) from Ureje Dam, Ado-Ekiti, Ekiti State. Nigeria. Journal of Biological and Physical Sciences 3: 111-114. 
Afkhami, F., A. R. Karbassi, T. Nasrabadi \& A. Vosoogh. 2013. Impact of oil excavation activities on soil metallic pollution, case study of an Iran southern oil field, Environmental Earth Science 70: 1219-1224.

Ahmed, M. K., N. Shaheen, M. S. Islam, M. Habibullah-al-Mamun, S. Islam, M. Mohiduzzaman \& L. Bhattacharjee. 2015. Dietary intake of trace elements from highly consumed cultured fish (Labeo rohita, Pangasius pangasius and Oreochromis mossambicus) and human health risk implications in Bangladesh. Chemosphere 128: 284-292.

Ahmet, D., Y. Fevzi, A. L. Tuna \& O. Nedim. 2006. Heavy metals in water, sediment and tissues of Leuciscus cephalus from a stream in southwestern Turkey. Chemosphere 63: 1451-1458.

Aiyesanmi, A. F. 2006. Baseline concentration of heavy metals in water samples from rivers within Okitipupa southeast belt of the Nigerian Bitumen field. Journal of Chemical Society of Nigeria 31(1\&2): 30-37.

Ali, M. M., M. L. Ali, M. S. Islam \& M. Z. Rahman. 2016. Preliminary assessment of heavy metals in water and sediment of Karnaphuli River, Bangladesh. Environmental Nanotechnology, Monitoring and Management 5: 27-35.

Anyanwu, E. D. \& S. N. Umeham. 2020. Identification of waterbody status in Nigeria using predictive index assessment tools: a case study of Eme River, Umuahia, Nigeria. International Journal of Energy and Water Resources, March 2020. https://doi.org/10.1007/s42108-020-00066-5

Atobatele, E. O. \& G. O. Olutona. 2013. Spatio-seasonal physico-chemistry of Aiba stream, Iwo, Nigeria. African Journal of Biotechnology 12(14): 1630-1635.

Backman, B., D. Bodis, P. Lahermo, \& S. Rapant. 1997. Application of a groundwater contamination index in Finland and Slovakia. Environmental Geology 36 (1-2): 55-64.

Balakrishnan, A. \& A. Ramu. 2016. Evaluation of Heavy Metal Pollution Index (HPI) of Ground Water in and around the Coastal Area of Gulf of Mannar Biosphere and Palk Strait. Journal of Advanced Chemical Sciences 2(3): 331-333.

Biswas, P. K., N. Uddin, S. Alam, Tamjid-Us-Sakib, S. Sultana \& T. Ahmed. 2017. Evaluation of Heavy Metal Pollution Indices in Irrigation and Drinking Water Systems of Barapukuria Coal Mine Area, Bangladesh. American Journal of Water Resources 5(5): 146-151. doi: 10.12691/ajwr-5-5-2.

Ebrahimpour, M. \& I. Mushrifah. 2008. Heavy metal concentrations in water and sediments in Tasik Chini, a freshwater lake, Malaysia. Environmental Monitoring and Assessment 141: 297-307.

Etesin, U., E. Udoinyang \& T. Harry. 2013. Seasonal Variation of Physicochemical Parameters of Water and Sediments from Iko River, Nigeria. Journal of Environment and Earth Science 3(8): 96 - 110.

Hakan, P. 2006. The distribution and sources of heavy metals in Izmit Bay surface sediment affected by a polluted stream. Marine Pollution Bulletin 52: 11971206 
Hammer, O., D. A. T. Harper \& P. D. Ryan. 2001. PAST: Paleontological Statistics Software Package for Education and Data Analysis, Paleontologia Electronica, 4: 9.

Horton, R. K. 1965. An index system for rating water quality. Journal of Water Pollution Control Federation 3: 300-315.

Houssou, A. M., S. Ahouansou Montcho, E. Montchowui. \& C. A. Bonou. 2017. Spatial and Seasonal Characterization of Water Quality in the Ouémé River Basin (Republic of Benin, West Africa). Egyptian Journal of Chemistry 60(6): 10771090.

Kelepertzis, E., 2014. Investigating the sources and potential health risks of environmental contaminants in the soils and drinking waters from the rural clusters in Thivaarea, Greece. Ecotoxicology and Environmental Safety 100: 258-265

Klavins, M., A. Briede, V. Rodinov, I. Kokorite, E. Parele \& I. Klavina. 2000. Heavy metals in Rivers of Latvia. Science of Total Environment 262: 175-183

Krishna, A. K., M. Satyanarayanan \& P. K. Govil. 2009. Assessment of heavy metal pollution in water using multivariate statistical techniques in an industrial area: a case study from Patancheru, Medak District, Andhra Pradesh India. Journal of Hazardous Materials 167: 366-373.

Kumar, S., V. K. Bharti, K. B. Singh \& T. N. Singh. 2010. Quality assessment of potable water in the town of Kolasib, Mizoram (India). Environmental Earth Science 61(1): 115-121.

Milenkovic, N., M. Damjanovic. \& M. Ristic. 2005. Study of heavy metal pollution in sediments from Iron Gate (Danube River), Serbia and Montenegro. Polish Journal of Environmental Studies 14: 781-787.

Muhammad, S., M. T. Shah \& S. Khan. 2011. Health risk assessment of heavy metals and their source apportionment in drinking water of Kohistan region, northern Pakistan. Microchemical Journal 98: 334-343

Nasrabadi, T. 2015. An Index Approach to Metallic Pollution in River Waters. International Journal of Environmental Research 9(1): 385-394.

Ojekunle, O. Z., O. V. Ojekunle, A. A. Adeyemi, A. G. Taiwo, O. R. Sangowusi, A. M. Taiwo \& A. A. Adekitan. 2016. Evaluation of surface water quality indices and ecological risk assessment for heavy metals in scrap yard neighbourhood. SpringerPlus 5: 560. DOI: 10.1186/s40064-016-2158-9.

Oves, M., M. S. Khan, A. Zaidi \& E. Ahmad. 2012. Soil contamination, nutritive value, and human health risk assessment of heavy metals: An overview. In: Zaidi, A., P. A. Wani \& M. S. Khan (eds). Toxicity of heavy metals to legumes and bioremediation. Springer, Vienna. pp. 1-27.

Pekey, H., D. Karaka \& M. Bakoglu. 2004. Source apportionment of heavy metals in surface waters of a polluted stream using multivariate statistical analyses. Marine Pollution Bulletin 49: 809-818.

Pillay, S., K. Naidoo, A. Bissessur, N. Agjee, K. Pillay, B. Purves, R. Pillay \& H. Ballabh. 2014. Sand Mining Impacts on Heavy Metal Concentrations in Two 
Important River Systems of Northern Kwazulu-Natal, South Africa. Journal of Human Ecology 47(2): 155-162.

Popović, N. Z., J. A. Đuknić, J. Ž. Čanak Atlagić, M. J. Raković, N. S. Marinković, B. P. Tubić, et al. 2016. Application of the water pollution index in the assessment of the ecological status of rivers: a case study of the Sava River, Serbia. Acta Zoologica Bulgarica 68(1): 97-102.

Prasad, B. \& J. M. Bose. 2001. Evaluation of heavy metal pollution index for surface and spring water near a limestone mining area of the lower Himalayas. Environmental Geology 41: 183-188.

Prasad, B., P. Kumari, S. Bano \& S. Kumari. 2014. Ground water quality evaluation near mining area and development of heavy metal pollution index. Applied Water Science 4: 11-7.

Prasanna, M. V., S. Chitambaram, A. S. Hameed \& K. Srinivasamoorthy. 2011. Hydrogeochemical analysis and evaluation of groundwater quality in the Gadilam river basin, Tamil Nadu, India. Journal of Earth System Science 120(1): 85-98.

Roshan, G., A. Ghanghermeh, T. Nasrabadi \& B. J. Meimandi. 2013. Effect of Global Warming on Intensity and Frequency Curves of Precipitation, Case Study of Northwestern Iran. Water Resources Management 27: 1563-1579.

Sharma, B. \& S. Tyagi. 2013. Simplification of Metal Ion Analysis in Fresh Water Samples by Atomic Absorption Spectroscopy for Laboratory Students. Journal of Laboratory Chemical Education 1(3): 54-58.

SON. 2015. Nigerian standard for drinking water quality. Nigerian Industrial Standard (NIS 554-2015). Standards Organisation of Nigeria (SON), Abuja, Nigeria. p.18

Tam, N. F. Y. \& W. S. Wong. 2000. Spatial variation of heavy metals in surface sediments of Hong Kong mangrove swamps. Environmental Pollution 110: 195-205.

Zhang, C. 2007. Fundamental of Environmental Sampling and Analysis, Wiley, New York. 456pp.

Received: $11^{\text {th }}$ November 2019; Accepted: 04 ${ }^{\text {th }}$ April 2020; Published: 01th Jule 2020. 